\title{
Making infrastructure reform in Latin America work for the poor
}

\author{
Antonio Estache \\ aestache@worldbank.org \\ Ten years of infrastructure reform in Latin America can teach \\ Vivien Foster \\ vfoster@worldbank.org \\ Quentin Wodon \\ us a lot about how to make privatization work for the poor. \\ There are macroeconomic and microeconomic transmission \\ mechanisms through which such reform may affect those \\ sectors. This paper discusses policy instruments to increase \\ qwodon@worldbank.org \\ their access to services and make the latter more affordable \\ World Bank \\ for them. The advantages and disadvantages of each \\ instrument are evaluated and examples are given. The ways \\ in which policy-makers should go about setting social \\ priorities in infrastructure reform and choosing the most \\ appropriate policy instruments in each case are then \\ considered. Emphasis is placed on the need for simple and \\ rapid empirical diagnostic tools, and finally it is stressed \\ that a pro-poor reform strategy requires a political \\ commitment from the outset of the reform process and an \\ integrated approach between privatization, social and \\ regulatory policy.
}




\section{Introduction}

Since 1990, more than 120 developing countries have invited the private sector to participate in the provision of infrastructure services. Latin America has achieved a higher degree of private sector participation than any other region, attracting about $50 \%$ of private capital flows to developing country infrastructure sectors during the 1990s. Indeed, by the year 2000, $90 \%$ of Latin American countries had achieved some degree of private sector participation in their electricity, telecommunications and transport sectors, and almost half have private participation in their drinking water sectors. Notwithstanding the widespread adoption of private sector participation, however, the infrastructure reform process -both in Latin America and beyondhas raised significant social concerns. Many argue that privatization leads to tariff increases that make services unaffordable for the poor, and that it hands over operational responsibilities to profit-orientated multinationals that have no commercial interest in extending services to urban slums and isolated villages. In a number of well-known examples, the social unrest created by private sector participation ultimately led to the demise of the whole process (Cochabamba, Bolivia), or necessitated major contract renegotiations (Buenos Aires, Argentina).

Concern for social issues only came as an afterthought in many reforming countries, and they

\footnotetext{
$\square$ This article is based on a study financed by the Regional Studies Programme of the Office of the Chief Economist (Guillermo Perry) of the World Bank Regional Office for Latin America and the Caribbean. For the complete text of the study, see Estache, Foster and Wodon (2002). Danny Leipziger, Nora Lustig and Michael Walton were members of the relevant advisory committee. The study was financed by the World Bank Institute and the Energy Sector Management Assistance Programme (ESMAP), a project designed to provide Latin America with assistance in the field of energy for persons with low incomes. Various sections of the study were presented at seminars in Argentina, Finland, Senegal and Uruguay and at the conference on Latin American infrastructure reform organized by the World Bank and the National Economic and Social Development Bank of Brazil (Rio de Janeiro, September 2001). The authors wish to express their special thanks to Phil Gray, Luis Serven and Catherine Waddams for their valuable comments. The views expressed in this article are those of the authors and do not necessarily represent those of the World Bank, its Executive Directors or the countries they represent.
}

were often addressed only in order to resolve conflicts. This is a policy failure in a region where more than a third of the population is poor. Fiscal and efficiency concerns dominated the agenda of policy-makers pressed by the severity of macroeconomic problems (Benítez, Chisari and Estache, 2000). Indeed, almost $60 \%$ of the private capital flows to the infrastructure sectors in Latin America during the 1990s were captured by the State in the form of privatization proceeds rather than invested directly in the sector. Even so, overall the infrastructure reform process has brought significant benefits to the Latin America region, generating US\$ 290 billion of private capital flows during the 1990s and leading to substantial improvements in the efficiency of infrastructure services. In Argentina, for example, it is estimated that the efficiency gains resulting from privatization amounted to one percentage point of GDP (Chisari, Estache and Romero, 1999). Moreover, there have also been some positive examples of how privatization can be made to work for the poor and provide the basis for a more conscious strategy of harnessing public-private partnerships to meet social objectives that cannot be fully financed from government resources.

This paper aims to distill the lessons of ten years of infrastructure reform experience in Latin America about how to make infrastructure privatization work for the poor (Estache, Foster and Wodon, 2002; Ugaz and Waddams Price, 2002). The paper is intended for the benefit of countries that are about to embark on infrastructure reform, or to make significant 'second generation' policy adjustments. A menu of options is provided, from which policy-makers can select the most suitable pro-poor infrastructure reform strategy for any particular country or sector. The structure of the paper is a follows: section II provides an overview of the macroeconomic and microeconomic transmission mechanisms through which infrastructure reform can affect the poor, with the primary focus centered on the microeconomic linkages, notably the ways in which reform affects access to infrastructure services by the poor and the affordability of those services for them. In section III we discuss policy instruments that can be used to ensure that infrastructure reforms result in increased access to services by the poor. The advantages 
and disadvantages of each instrument are evaluated, and a number of concrete examples provided. In section IV, we review the policy instruments that can be used to ensure that infrastructure services remain affordable to poor households following reform of the sector, and once again the advantages and disadvantages of each instrument are evaluated and examples given.

Section V considers how policy-makers should go about setting social priorities in infrastructure reforms and choosing the most appropriate policy instruments for each case, with emphasis on the need for simple and rapid empirical diagnostics of how infrastructure services affect the poor, and finally section VI explains why the definition of a pro-poor reform strategy requires a political commitment from the outset of the reform process, as well as the adoption of an integrated approach between privatization, social and regulatory policies.

\section{II \\ Macro and micro linkages between reform and the poor}

From a macroeconomic perspective, there are three ways in which infrastructure reform can have an impact on the welfare of the poor: by promoting economic growth; by affecting employment levels; and by reallocating public expenditures.

Infrastructure investments are important for economic growth, which is in turn one of the main engines of poverty reduction. Evidence from Bolivia, Colombia, Mexico and Venezuela indicates that a $10 \%$ increase in infrastructure stocks has been found to lead to a $1.5 \%$ increase in GDP (Canning, Fay and Perotti, 1992; Canning, 1998; De la Fuente, 2000), which is important because in Latin America a single percentage point of growth reduces the number of people living in poverty by half a percentage point (Wodon, 2000d). There is also evidence from Argentina and Brazil that differentials in infrastructure endowments (such as roads and access to sanitation) have been a significant impediment to convergence between rich and poor regions over the last 20 years (Eberts, 1990; Estache and Fay, 1995; Ferreira, 1996; Ferreira and Malliagros, 1998).

Another consequence of privatization and reform is the shedding of labour to raise the efficiency and profitability of infrastructure service providers. In Argentina the utilities workforce shrank from 300,000 in the 1980s to around 50,000 by 1993 (Alexander, 2000). The immediate impact of such layoffs can be cushioned by the design of adequate labour redundancy packages, and in the longer run -to the extent that sector reform contributes to economic growth and thereby new jobs- the initial layoffs in the public utilities may be compensated by job creation in other sectors (Galal et al., 1994). Still, the transition is difficult and should be a major item of concern for policy-makers.

Finally, infrastructure services have traditionally absorbed large volumes of public resources to cover operating subsidies and finance new investments. Reform of the sector and the participation of private capital offer the opportunity to make these services financially self-sufficient, thereby freeing up fiscal resources for other programmes. To the extent that these funds are diverted to programmes whose incidence is more progressive than that of the original infrastructure subsidies, there is potential for reform to benefit the poor (Baffes and Shah, 1998). In Colombia, for instance, subsidies for the consumption of utility services such as water, sewerage, electricity and gas are substantially less progressive than public expenditures on health, education and rural development (Vélez, 1995).

The microeconomic linkages between infrastructure reform and the poor fall into two categories, namely those that affect either access to services by the poor, or their capacity to pay for them. Table 1 summarizes the main linkages between infrastructure reform and the poor, and identifies the corresponding mitigating policy instruments that will be described in greater detail in the following sections.

Reform and private sector participation can affect access to infrastructure services in many ways. Reform may lead to increases in the initial connection fees for infrastructure services that may historically have been provided at minimal charge. Typical connection fees

MAKING INFRASTRUCTURE REFORM IN LATIN AMERICA WORK FOR THE POOR - ANTONIO ESTACHE, 
TABLE 1

Microeconomic linkages between infrastructure reform and the poor

\begin{tabular}{|c|c|c|}
\hline Access & Impact & Mitigating policy instruments \\
\hline Rising connection charges & $\begin{array}{l}\text { The connection charge may increase substantially } \\
\text { with the arrival of private operators who must recoup } \\
\text { the costs of network expansion. }\end{array}$ & $\begin{array}{l}\text { - Select cheaper technologies for network expansion. } \\
\text { - Provide credit for repayment of connection charges. } \\
\text { - Allow households to contribute labour for civil } \\
\text { works. } \\
\text { - Cross-subsidize connection costs through user } \\
\text { tariffs. } \\
\text { - Provide connection subsidies to poor households. }\end{array}$ \\
\hline Diluting incentives & $\begin{array}{l}\text { It may not be commercially attractive for private } \\
\text { operators to serve poor customers who live in costly } \\
\text { outlying areas, consume modest amounts of the } \\
\text { service, and may not be accustomed to paying. }\end{array}$ & $\begin{array}{l}\text { - Impose universal service obligations on operators. } \\
\text { - Specify connection targets in low-income areas. } \\
\text { - Provide connection subsidies to poor households. }\end{array}$ \\
\hline Outlawing alternatives & $\begin{array}{l}\text { Privatization may restrict access to some alternative } \\
\text { services, especially if connection to public network is } \\
\text { mandatory. }\end{array}$ & $\begin{array}{l}\text { - Oblige dominant utilities to provide alternative } \\
\text { - Allow licensed entry of alternative suppliers. } \\
\text { - Promote partnerships between dominant utility and } \\
\text { alternative suppliers. }\end{array}$ \\
\hline
\end{tabular}

\begin{tabular}{lll}
\hline Affordability & Impact & Mitigating policy instruments \\
\hline Increasing tariffs & $\begin{array}{l}\text { Average tariff levels can increase substantially }(10 \% \\
\text { to } 100 \%) \text { due to cost recovery requirements. }\end{array}$ & $\begin{array}{l}\text { Introduce lifeline tariffs. } \\
\text { Apply targeted tariff discounts. Provide vouchers } \\
\text { for services. } \\
\text { Reduce fixed charges. }\end{array}$
\end{tabular}

of

Formalizing payment

Rebalancing tariffs

Raising quality standards
In order to improve revenue collection, private operators will formalize illegal connections and enforce billing on pain of disconnection.

The removal of historic cross-subsidies may accentuate increases in tariffs of services used by the poor.

Average tariff levels can increase, due to more demanding quality-of -service standards consumption.

- Increase frequency of billing.

- Use prepayment devices.

See above.

See above.

- Where possible, allow operators to provide different price and quality combinations to different customer groups.

Source: Prepared by the authors.

charged by the private sector are of the order of several hundred US dollars, and are thus beyond the economic reach of poor households, unless there is some kind of option to pay by installments. There is thus a danger that poor households may not be able to afford service connections after the reform process. Low income families tend to live in outlying settlements that are costly to serve and consume only modest amounts of infrastructure services, which they may not even be accustomed to paying for. Since private operators are driven primarily by profit considerations rather than public policy objectives, they may not find it commercially attractive to extend services to low income customers. Finally, many poor households rely on informal alternatives to modern infrastructure services, such as private vendors, next door neighbours or self-supply. Reform processes sometimes attempt to outlaw these small-scale alternative providers, thereby reducing the options available to the poor.

There are also ways in which reform can raise affordability issues for those among the poor who already enjoy access to the services. First, in order to make infrastructure services financially self-sustaining, it may be necessary to increase tariffs that have been 
kept artificially below the cost of provision for many years. Tariff increases can be quite substantial (of the order of $10 \%$ to $100 \%$ ), but they are to some extent a political option and can be mitigated if the government is willing to accept a lower sale value for infrastructure assets. Moreover, where effective competition or incentive-based regulation is introduced, tariffs may decrease over time.

Second, State-owned utilities have traditionally taken a relaxed attitude to illegality and non-payment. In contrast, private operators have a strong incentive to insist on the formalization of illegal connections and enforce service payments (on pain of disconnection), so as to ensure the collection of enough revenue to cover operating costs. As a result, following sector reform, some poor households may find themselves paying for services for the first time. However, this is not necessarily a bad thing, since illegality is often not in the interest of poor households. Informal connections are often unsafe (contaminated drinking water, risks of electrocution), and may entail payments to local mafia bosses. Moreover, establishing a formal relationship with a utility can be a first step towards obtaining the proof of residence necessary to obtain credit and access to other services.

Third, in sectors where competition is introduced, it becomes necessary to phase out historical crosssubsidies between customer groups, leading to substantial tariff rebalancing. One example is the increase in local telephone charges and the corresponding decrease in long distance and international telephone charges that typically follows sector reform. To the extent that poor households make disproportionate use of services that historically benefited from cross-subsidies, they may be adversely affected (Gómez-Lobo, 1996).

Finally, the desire to improve service quality is often an important motivating factor in infrastructure reform. However, quality improvements generally require significant investments in upgrading infrastructure, and therefore feed through into higher service tariffs for consumers. While raising quality standards is clearly a desirable outcome, it may raise issues of affordability for low income households (Baker and Tremolet, 2000).

\section{III}

\section{Policy instruments for improving access to basic services}

While improvements in access to infrastructure services are more likely to be pro-poor than the current situation, the evidence suggests that the poor (and especially the very poor) still often do not benefit as much as others from gains in access (Ajwad and Wodon, 2002a and 2002b). Special efforts, programmes and regulatory oversight are needed in order to ensure that the benefits reach the poor. Table 2 reviews a number of instruments available for improving access to services for the poor, together with their advantages and disadvantages (see also Komives, Whittington and $\mathrm{Wu}, 2000$ ). These instruments are not mutually exclusive, and indeed successful examples of reforms in Latin America combine several of them. The instruments in table 2 fall into three categories: requiring operators to provide access; reducing connection costs; and increasing the range of suppliers.

\section{Requiring operators to provide access}

Let us first consider requirements to provide access. Regulatory measures can be used to counteract the lack of commercial incentives for serving low income customers. Universal Service Obligations are typically incorporated in licenses and concession contracts and require operators to provide services within a specified time period to any consumer that requests them within a specified geographical area. Although politically appealing, such obligations are not all that meaningful in practice because they fail to take into account the fact that low income households may not be able to afford service, and hence would not be in a position to request it (Chisari and Estache, 1999). They also overlook the fact that for communities that are beyond the existing network, service expansion needs to take

MAKING INFRASTRUCTURE REFORM IN LATIN AMERICA WORK FOR THE POOR - ANTONIO ESTACHE, 
TABLE 2

Summary of instruments for promoting access

\begin{tabular}{lll}
\hline & Advantages & Disadvantages
\end{tabular}

\section{Instruments requiring operators to provide access}

Universal Service Obligations Provide a legal obligation to serve all customers, including those that may not be commercially attractive.

Connection Targets

Force a concrete definition of realistic coverage targets, ensuring that unprofitable customers are served. Can be monitored and enforced by use of financial penalties.
The obligation is rather vague, and places the onus on the customer to request the service. This may not be very meaningful if poor customers cannot afford connection charges or live far away from existing networks.

Require symmetrical obligation on users to connect, which limits freedom of choice. Attention must still be given to affordability of connection charges if tariffs are to be met.

\section{Instruments reducing the cost of connection}

Low cost technologies

Credit lines

Connection subsidies

Connection cross-subsidies
Improve the affordability of infrastructure connections, without generating the need for subsidies, and reduce the overall investment cost of reaching universal access targets.

Allow households to contribute in terms of an abundant resource (time) rather than a scarce resource (money). Avoid need for external finance.

Address what is sometimes the real underlying problem: credit constraints rather than absolute affordability.

Target subsidy funds to low income individuals. Administrative costs are relatively low as a proportion of subsidies awarded. For community level subsidies, competitive forces can be used to keep costs down.

Do not require external source of funding and spread cost over a large connected population (often with greater ability to pay than the unconnected population). Somewhat equitable if connections were provided free of charge prior to privatization.
May lead to reduced quality of service.

There may be significant costs in training and supervising community volunteer labour.

If provided by private operator, may lead to increased risk exposure. Otherwise, require collaboration of micro-credit institutions.

Require government finance and are relatively costly per household connected. User co-financing should be required to ensure commitment.

Require the unconnected population to be small relative to the connected population. The connected population may be unwilling to shoulder the subsidy.

\section{Instruments that increase supply options}

Broader service obligations

Ensure that an alternative is available for households which are not able to connect to the network

Licensed entry of alternatives

Promotion of partnerships
Provides choice to consumers. Increases competitive pressures on the dominant utility.

Improve quality of supply to communities lacking connections to the dominant utility, while reducing commercial risk to dominant utility from serving marginal communities
Except in the case of telephones, there is evidence that even poor households prefer private connections. Communal supply points tend to be unprofitable and therefore need to be closely regulated.

May make investment unattractive to dominant utility. May be difficult to regulate small suppliers to ensure adequate quality of service.

May be difficult to achieve collaboration between the formal and informal sectors.

Source: Prepared by the authors. 
place in a coordinated fashion, and not simply at the request of an individual.

A tighter approach is to incorporate connection targets requiring the operator to make a specified number of new connections within a certain time period. In 1997, this approach was successfully used in the 30year water and sewerage concession for the twin cities of La Paz and El Alto in Bolivia (Komives and Brook, 1999; Carbonel, 2000; Foster and Irusta, 2001). The government awarded the concession to the private operator willing to make the largest number of new connections in the low-income neighbourhoods of El Alto. Thus, the winning bidder was contractually obliged to connect 72,000 families to piped water and 38,000 families to sewerage over a five-year period, and as a result the annual rate of new connections to both water and sewerage services increased by about $66 \%$ following the reform. Household survey evidence shows that the coverage of water in low income households in El Alto -which was almost static at $65 \%$ between 1989 and 1994-jumped to about $98 \%$ between 1994 and 1999.

This example illustrates that it is critical that the connection targets be geographically referenced to low income communities, otherwise the operator will meet them simply by taking services to the most lucrative segments of the market (which is what would have happened anyway in the absence of connection targets). Connection targets should be carefully monitored and enforced through financial penalties. Although they represent an improvement on the Universal Service Obligation, concerns about the affordability of connection charges remain valid. In practice, obligations to serve the poor are much more effective when they are combined with financial incentives. This could mean, for example, providing 'smart subsidies' to operators that connect poor consumers, or ensuring that the tariff revenue from serving poor customers fully covers the cost of service provision so that they are financially attractive to serve, even if a part of this cost is ultimately subsidized (Jadresic, 2000). These issues will be explored further in the next section.

\section{Reducing connection costs}

There are several instruments that can help to reduce connection costs for poor households. In many countries, there is a tendency to enforce rigid technological standards for infrastructure networks that are often comparable with those prevailing in industrialized countries (Brook and Tynan, 1999).
Although such standards guarantee a high-quality service, they may also have the effect of making the service so expensive that it is not affordable to the poor. Greater flexibility is called for, and governments should experiment with technologies that may provide a slightly lower quality of service but at a significantly lower cost. Also, while poor households are cash constrained, they may have labour time available, particularly if they live in areas affected by underemployment. It is often desirable to allow people to contribute part of the cost of a new connection 'in kind' by volunteering their labour (while recognizing that such volunteer labour may require a commitment from the utility in terms of training and supervision).

The 'condominium' approach to water and sewerage networks developed in Brazil during the 1980s shows how technological innovation can be used to reduce the costs of providing services to poor households. By routing networks through backyards and across sidewalks, instead of down the center of streets, savings are made in the length and diameter of pipes and the depth they need to be buried at. Community labour is also used to build the networks, which reduces costs and increases ownership. Overall, savings of the order of $40-50 \%$ have been achieved (Foster, 2001).

Another reason why poor households find it difficult to pay connection charges is that they do not have savings, nor access to credit, that would enable them to make a large capital payment. Connection charges may become affordable if they can be spread over a sufficiently long period of time and credit lines can be offered directly by the utility (in the form of payment by installments) or micro-credit institutions. Credits of this kind may also help households to finance housing investments needed to make full use of an infrastructure connection: for example wiring in the case of electricity, and plumbing in the case of water and sewerage (the cost of these complementary investments may be as high as the connection charge itself). There is also the possibility of providing direct government subsidies to cover at least some portion of the connection costs for customers who meet eligibility criteria (connection subsidies are easy to target when a high proportion of unconnected households are poor, and administrative costs can be kept low). Connection subsidies could also be allocated competitively to the operators willing to provide service at the lowest cost. Where public finance is not available, connection subsidies can be funded by a surcharge on all utility bills, or by special funds. This introduces a cross-

MAKING INFRASTRUCTURE REFORM IN LATIN AMERICA WORK FOR THE POOR - ANTONIO ESTACHE, 
subsidy from existing customers to new customers, since part of the cost of network expansion is covered through the service tariff, but it may be equitable if existing customers received their connections on a subsidized basis in the past.

One of the central objectives of the Buenos Aires water concession was to expand the access of low income households (Alcázar, Abdala and Shirley, 1999; Ferro, 1999). However, under the original terms of the contract, an infrastructure charge of 300-600 pesos for water and 800-900 pesos for sewerage was mandatory for new connections, and even with the possibility of paying by installments, such charges were out of reach for poor families living on 200-250 pesos per month. The high level of charges provoked civil unrest, leading to a renegotiation of the original concession contract, and the solution finally adopted was to levy a universal service fee of 6 pesos per month on all water customers and waive the infrastructure charge for new customers. This approach illustrates how the introduction of a cross-subsidy from existing to new customers was successful in overcoming the social problems caused by the original approach.

A slightly different approach has been taken in the telecommunications sector, where many countries have introduced rural funds as part of the reform process. These funds are financed from the proceeds of spectrum license auctions, or via universal service levies of the order of $1 \%$ on the turnover of the sector. The funds finance one-time capital grants to private operators willing to operate public telephones in commercially unattractive rural areas for at least 10 years, and they are competitively allocated to the operator requesting the lowest subsidy. Such programmes have succeeded in bringing public telephone services to 19,000 rural communities in four countries. Moreover, every dollar of public subsidy has leveraged at least two dollars of private investment.

\section{Increasing the range of suppliers}

There are several instruments which can also help to increase the range of suppliers. Many poor households are served by small-scale alternative providers who frequently offer a balance of cost and quality that is better suited to low income customers than services provided by conventional utilities (Erhardt, 2000). When it is simply not feasible to achieve universal access to network services quickly, alternative services may be the only option available. It is thus important to ensure that the reform process takes into account the potential role of these providers in reaching the poor (Solo, 1999a and 1999b; Solo and Paniagua, 1999).

In some instances there may be genuine problems in relying on alternative service providers: for example, if they represent a major water quality risk or involve irrational exploitation of common-property water resources. Where this is the case, it makes sense to redefine the legal obligation of the dominant utility from providing a particular technology (e.g., piped water) to providing a service (e.g., drinking water to the household) by whatever technological means is appropriate (whether it be public tankers, public standpipes, or resale via a street vendor or neighbour). In this way, the dominant utility is required to take into account the needs of all the population and not simply those that are already connected to a modern infrastructure network.

In cases where alternative providers do not present conflicts with the public interest, they should be regarded as part of the solution, rather than part of the problem. Thus, far from being outlawed they should be given full legal status equivalent to that enjoyed by the formal utility (Kariuki and Acolor, 2000). Where feasible and appropriate, they should also be submitted to some regulatory control to ensure that they do not exploit customers, either in terms of the prices that they charge or the safety of the services they provide. Finally, small-scale alternative providers may work in partnership with the conventional utility, each building on their respective strengths and complementarities. For example, the utility may have a comparative advantage in the bulk production of potable water, while smallscale providers may have a comparative advantage in billing and distributing water in precarious peri-urban settlements. The regulatory framework should be sufficiently flexible to contemplate such partnerships when they are in the interests of the end consumer. 


\section{IV}

\section{Policy instruments for improving consumption affordability}

Infrastructure reform processes often lead to tariff increases. Tariff structures that have significant standing charges or minimum monthly consumption charges can be particularly unfavourable to low-income customers who consume small amounts of the service. From a social perspective, it is desirable to keep these charges low, while recognizing that for the utility such charges may be an important reflection of the fixed costs associated with billing and servicing customers. In general terms, table 3 suggests instruments that can be used to safeguard the affordability of services, together with an overview of their advantages and disadvantages. In many cases, there are gains from using several instruments at the same time, since many are complementary to each other. ${ }^{1}$ Broadly, such instruments influence affordability in at least one of three ways: reducing the bills to be paid by poor households; reducing the cost of services; and facilitating the payment of bills. Whatever the option chosen, when designing tariffs and subsidies that help to reduce the utility bills paid by poor households, care must be taken to establish simple, transparent and accurate eligibility criteria for identifying the poor and to avoid perverse distortions in the behaviour of utilities and their customers.

\section{Reducing the bills faced by poor households}

A popular way of reflecting social concerns in tariff structures is to define a "lifeline" subsistence consumption block that is provided below its economic cost (Maddock and Castaño, 1991; Garbacz and Thompson, 1997). In some cases, the lifeline is available to all customers, while in others it is targeted only at specific customer groups. The revenue shortfall from lifeline consumption can be covered by the State or by a cross-subsidy from those consuming higher volumes of the service. Lifeline tariffs are based on the assumption that poor consumers tend to be small

\footnotetext{
${ }^{1}$ An interesting example of using instruments jointly is that of Electricité de France (EDF) in France (see Wodon, 2000a, 2000b and 2002c).
}

consumers. This is not necessarily true, however, if one takes into account the prevalence of large families, shared dwellings, and the practice of secondary retailing of services between neighbours.

The available empirical evidence indicates that the existing lifeline tariffs may not be very effective at reaching the poor. The electricity tariff in Honduras, for example, provides subsidized power to all domestic consumers using less than $300 \mathrm{kWh}$ per month, at an annual cost of US\$17 million to the government. However, analysis shows that about $80 \%$ of this subsidy goes to non-poor households. The reason is that many poor people remain unconnected to the network, and those that are connected consume well below $300 \mathrm{kWh}$ per month (Wodon, Ajwad and Siaens, 2002). A similar policy exists in Guatemala, where the annual cost of US\$50 million is financed via cross-subsidies from commercial and industrial customers. Given that only $40 \%$ of poor families in Guatemala have access to electricity, about $90 \%$ of the value of the subsidy goes to benefit the non-poor (Foster and Araujo, 2002).

An alternative to lifeline tariffs is to use identifying characteristics (means-testing) to target discounts on the poor. In some countries, place of residence is used to determine eligibility. Elsewhere, eligibility is based on socioeconomic characteristics or on the characteristics of the connection. Once again, the discounts can be financed by the State or via crosssubsidies from households that do not qualify. One option is to treat cross-subsidies as a surcharge on utility bills that goes into a trust fund for financing social tariffs. Utilities are then allowed to draw upon these resources against certified evidence that they are providing discounted service tariffs to identified lowincome consumers. A drawback of means-testing versus lifeline systems is the need to incur administrative costs for screening customers for eligibility, but this cost can be reduced by using a similar targeting mechanism for many different programmes (Foster, Gómez-Lobo and Halpern, 2000; Clert and Wodon, 2001). Furthermore, Wodon, Ajwad and Siaens (2002) show that meanstesting can be much more efficient in identifying the poor than lifeline tariffs, so that it should more than 
TABLE 3

Summary of instruments for promoting affordability

\begin{tabular}{cc}
\hline Advantages & Disadvantages \\
\hline
\end{tabular}

Instruments reducing bills paid by poor households

Lifeline tariffs $\quad$ Entail minimal administrative costs.

Targeted tariff discounts

May provide a more reliable way of identifying low-income households.

Vouchers

Tariff re-balancing
May provide a more reliable way of identifying low income households, give added flexibility for user to select service provider, and ensure that low income customers remain commercially attractive.

Reduces burden of fixed costs on small consumers
Based on the questionable assumption that poor customers are small consumers. However, as a result of large families, shared dwellings, and reliance on secondary retailing (sales between neighbours) this will not necessarily be the case.

It is difficult to find good targeting variables, and administrative costs may be significant. May be difficult to raise subsidy or cross-subsidy funds.

May be administratively complex and open to abuse; remains difficult to identify good targeting variables and raise fiscal funds.

The overall impact on affordability may not be large, and utilities may need to cover fixed costs of billing.

Instruments reducing cost of service

Lower quality of service Allows consumers to choose their preferred balance between the cost and quality of service.

Consumption limiting devices Prevent low income households from consuming beyond their means.
May not always be technologically possible to differentiate quality of service provided through a common network.

May lead to hardship if basic needs exceed imposed consumption ceiling. Moreover, required metering technology may be prohibitively expensive. Also runs against the private operator's commercial incentives.
Instruments facilitating payment of bills

Billing frequency

Facilitates budgeting for low income households

Prepayment devices

Facilitate budgeting for low income households
Increases administrative costs of revenue collection, but may improve revenue collection rates.

May lead to 'self-disconnection'. May be costly and subject to fraud. Requires the creation of a network for selling 'smart cards' if electronic technology is used.
Source: Prepared by the authors.

compensate for the administrative costs involved. Under means-testing, some discounts may take the form of vouchers defraying the cost of utility bills while allowing users to select their service provider. While voucher schemes may be complex, the basic principle of applying the same cost-reflective tariffs to all customers (while providing vouchers) is important because it ensures that low-income customers remain commercially attractive to utilities.
Colombia provides an interesting example of geographically targeted discounts for the poor. The scheme is endorsed by the Constitution of 1991, which requires utility tariffs to be based on principles of social solidarity. This has been achieved by classifying all neighbourhoods in the country into one of six socioeconomic strata, based on the quality of housing (for example, the materials with which it is constructed) and the extent of neighborhood amenities (such as street 
lighting, green areas). According to the 1994 Public Utilities Law, neighbourhoods in strata one to three may have their tariffs subsidized by a maximum of $50 \%$ for strata one, tapering down to $15 \%$ for strata three. The resulting revenue shortfall is covered from a surcharge of up to $20 \%$ to be applied to the bills of households in strata five and six, as well as commercial and industrial customers. The scheme is successful in reaching the poor ( $95 \%$ of them live in neighbourhoods belonging to strata one to three), but there is also high leakage ( $80 \%$ of residents of those three types of neighbourhoods are not poor) (Contreras and GómezLobo, 2000).

\section{Reducing the cost of services}

Another way of keeping services affordable for poor households is to reduce the cost of providing them. This can be achieved either by providing a lower quality of service or by placing physical limits on the amount of the service that a household can consume. Poor households may prefer to accept a lower quality of service, if in return they are charged a lower tariff. Yet, in practice, most utilities tend to offer a single service level, which is determined with reference to industrialized country standards and may therefore be unaffordable for poor households. While safety standards should not be compromised, there may be other ways to differentiate the quality of service provided to different customer groups. One example is reliability, where some customers may be willing to accept a higher frequency of service interruptions in return for a lower tariff. Of course, this kind of approach must be based on consultation with the affected communities. Another complaint made by low income households is that utility bills are unpredictable, and that it is therefore difficult to keep consumption within affordable limits. One possibility here is to install physical devices that limit the amount of the service that can be drawn through the connection. In the case of electricity, this takes the form of load limiters, which restrict the total number of appliances that can be switched on at the same time, while in the case of water, small-diameter connections can be used to limit the flow of water into a dwelling. In telephony, it is easy to cap the number of minutes of use each month. The advantage of these devices is that they keep consumption levels -and hence utility bills- below a predetermined upper limit.

\section{Facilitating payment of bills}

A key difference between modern utilities and traditional substitutes is the frequency of payment. Whereas households buy candles and tankered water on a daily or weekly basis, electricity and piped water are typically billed no more than once per month. Since poor households have negligible reserves of working capital, it may be difficult to pay for a whole month's consumption in one go. One solution is for utilities to bill more frequently, although this entails higher administrative costs. Alternatively, 'utility stamps' can be sold through retail outlets so that households can pay for services gradually during the course of the month. Another way of giving households payment flexibility is to use prepayment devices rather than standard billing. This reduces the commercial risk faced by utilities, since customers are not given credit for the use of the service. Prepayment systems have been successful in widening the ownership of cellular telephones. However, in some sectors prepayment meter technologies remain expensive to install.

An example of the successful use of prepayment devices comes from Bolivia, where until 1995 cellular telephony services were the monopoly of Telefónica Celular de Bolivia (Telecel). The cost of a telephone was high, and subscribers were required to pay for both incoming and outgoing calls. In 1995, however, a second cellular license was awarded to the Empresa Nacional de Telecomunicaciones (Entel), and with the advent of competition, the 'calling party pays' rule was adopted, leading to an effective reduction of about $70 \%$ in the cost of using a cellular telephone. Prepayment telephones were also introduced with payment card denominations as low as US\$ 5. As a result, the number of cellular subscribers in Bolivia has grown by a factor of ten between 1996 and 1999, and prepaid telephones have accounted for $86 \%$ of the growth in mobile telephony since 1998. Evidence suggests that many prepaid telephone subscribers are artisans and micro-entrepreneurs who use the telephone mainly for receiving calls from clients, keeping their own expenditures under control by purchasing low value phone cards. A wide variety of systems for facilitating the payment of bills have also been implemented in many OECD countries (Wodon, 1999 and 2000a). 


\section{Defining pro-poor infrastructure reform strategies}

In the preceding sections we identified ways in which infrastructure sector reform may prejudice the poor, and we presented instruments to attenuate such impacts. In order to apply these concepts to a particular country or sector, it is necessary to have a good empirical understanding of the social dimensions of infrastructure services. Much of the needed information may already be available from existing sources, such as census data, household surveys or utility databases. However, significant efforts are often required to pull it all together. In some cases, it may be necessary to contemplate new survey work to collect information on important policy variables, which can then be used to answer three key questions: i) should the primary policy focus be on improving access or affordability?; ii) which policy instruments are likely to be the most effective in reaching these goals?; and iii) which infrastructure services should be given the highest social priority?

Both access and affordability are important, and there is no point in providing poor households with access to a service that they cannot afford. Nevertheless, resources are constrained and it is often necessary to focus attention on one objective or the other. In general, improving affordability is more likely to benefit the better-off, rather than increasing access for those who are not yet connected, partly because the second group is poorer. There may, however, be a threshold beyond which providing additional access may be less povertyreducing than providing subsidies to those who already have access (Wodon and Ajwad, 2002). There is also evidence that households with network access are able to satisfy their basic needs much more cost-effectively than those without. For example, in Guatemala households with electricity pay less than US $\$ 0.10$ per kilowatt-hour to light up their homes, while those without rely on candles that cost the equivalent of US\$ 5 per kilowatt-hour (Foster and Tre, 2000; Foster, Tre and Wodon, 2000). Similarly, in Port-au-Prince, Haiti, households with piped water connections pay US\$1.00 per cubic meter, while those without pay US $\$ 10$ per cubic meter to obtain water from private vendors.

Simple diagnostic tools can be used to determine whether access charges are affordable to the poor. For example, the connection charge can be divided by the monthly income of a typical poor household, and if no direct information on monthly income is available, the minimum wage or poverty line can be used instead. While there are no hard and fast rules, the resulting ratio gives an idea of how unaffordable connection charges may be. For example, if the connection charge represents six months of family income, it is clearly beyond the economic reach of the poor. It is also important to find out whether the utility offers the possibility of payment in installments, and if so, what proportion of monthly income such installments represent for the poor. For example, if each installment absorbs $25 \%$ of monthly income, then the service remains unaffordable in spite of the opportunity to pay by installments. One can also assess the extent to which poor households connect to utility services when infrastructure networks are available in their communities. Recent evidence from Guatemala and Honduras shows that up to a third of households without access to electricity and piped water live next to public mains and distribution lines, but nonetheless they are not connected (Foster and Araujo, 2002; Estache, Foster and Wodon, 2002). While there are a number of potential explanations for this phenomenon, it clearly suggests that the connection may not be affordable.

Similarly, simple diagnostic tools exist for assessing the affordability of using a service. For example, the amount that connected poor households pay for the service as a percentage of their total household budget can be computed. If expenditure data are available, it is possible to infer the physical amount of the service that families are consuming, and compare this to a subsistence benchmark, to see whether the poor are consuming 'enough'. It is also possible to compare the expenditures of low income connected households on utility services with the amount paid for substitute services by similar low income households that do not enjoy network access. In Guatemala, poor households with access to electricity spend as much on lighting and powering appliances as poor households without electricity do for comparable purposes, but the former derive much more benefit from their electricity connections than the latter do from substitute sources. Even when household survey data are not available, the utility tariff structure itself can be used to calculate

MAKING INFRASTRUCTURE REFORM IN LATIN AMERICA WORK FOR THE POOR - ANTONIO ESTACHE, 
the monthly bill for a reference level of subsistence consumption and compare this with the typical monthly income of a poor household. Where the necessary resources are available, another possibility is to conduct a household survey designed to measure the stated willingness to pay for the service.

Once priorities have been identified, the next step is to select instruments for promoting access, affordability, or both. While some instruments have no budgetary implications, others do, in which cases costs must be estimated, taking into account administrative costs, say, for screening eligible households. Since an important part of the cost is due to resources that 'leak away' to households that were not intended to be beneficiaries, it is important to make a realistic evaluation of the likely targeting performance of the subsidy or policy (Contreras and Gómez-Lobo, 2000). It is also difficult to design a subsidy programme that does not introduce some kind of perverse incentive. For example, subsidies may reduce commercial incentives for utilities to serve poor customers, by reducing the revenue that they capture from doing so. Subsidies can also distort the behaviour of consumers, by generating potentially wasteful consumption, efforts to qualify for the subsidy by fraudulent means, attempts to sell or pass on subsidy benefits to non-eligible consumers, or reduced interest in improving income and living conditions in order to avoid losing eligibility (poverty trap mechanisms). Subsidies linked to location or the characteristics of dwellings may also be capitalized in the rental value of the property, thereby reducing the benefits for poor tenants. Finally, while social policies tend to be designed on a sector-by-sector basis, overall budget constraints mean that governments also need to take into account priorities within infrastructure sectors, as well as between infrastructure and other sectors.

A number of analytical tools have been developed in recent years to aid decisions on which types of subsidies to provide. By using Consumption
Dominance curves, it is possible to compare the poverty-reducing impact of subsidies to different sectors (Makdissi and Wodon, 2002). ${ }^{2}$ Results for Latin American countries suggest that subsidies for water and urban transport have more impact on poverty than subsidies for electricity and telephony. By decomposing measures of inequality across different components of expenditure, it is possible to identify how subsidies are likely to affect inequality (see for example Wodon and Yitzhaki, 2002). In Mexico, this methodology suggested among others that subsidies for water reduced inequality, subsidies for electricity were neutral in this respect, and subsidies for telecommunications increased inequality. Finally, the impact of subsidies and access on inequality measures can be compared, taking into account the value of access for households which are connected to the network, by using hedonic regressions, for example (Siaens and Wodon, 2002).

Table 4 summarizes the main questions that must be answered in order to define a strategy for pro-poor infrastructure reform and identifies the information that needs to be collected to provide well-founded empirical answers to those questions. Figure 1 provides a simple decision tree for determining priorities between access and affordability issues.

\footnotetext{
${ }^{2}$ Consumption Dominance or CD curves are used to test whether the reduction in poverty induced by a marginal tax reform, a price reform, or a subsidy reform for two commodities is robust over a large set of poverty measures and poverty lines. The method is similar in spirit to checking for non-intersecting concentration curves, but it enables the analyst to choose the so-called order of stochastic dominance of interest, rather than being limited to the second order of dominance. Moreover, the method extends previous results for the impact of tax, price, or subsidy reforms on poverty measures of the Foster-Greer-Thorbecke (FGT) type to a larger class of poverty measures, and to cases where there is a differential in the efficiency cost of raising public funds through various commodities (or, more generally, differences in the behavioral impact of tax, price and subsidy reforms). For details, see Makdissi and Wodon (2002).
} 
TABLE 4

Summary of strategic questions and information needs

\begin{tabular}{ll}
\hline Questions & Information needs \\
\hline $\begin{array}{l}\text { What is the level of service coverage among } \\
\text { poor households? }\end{array}$ & $\begin{array}{l}\text { Conventional coverage statistics, broken down by income or consumption decile, } \\
\text { and preferably also by urban and rural areas. Percentage of households connected to } \\
\text { utility services which are poor. Unit price of utility service. Equivalent unit price of } \\
\text { substitute for utility service. }\end{array}$
\end{tabular}

Can the poor afford the initial costs associated with connecting to the network?

Can the poor afford to use infrastructure services once they have them?

What would be the cost of using the instrument?

Does the instrument perform well in targeting terms?

Would the instrument introduce perverse incentives?

What should be the prioritization between services?
Connection charge divided by typical monthly household income of the poor (e.g., two minimum wages, or the family poverty line). Minimum monthly installment required by utility to cover connection charge divided by typical monthly household income of the poor. Percentage of households living in communities served by utilities that are actually connected to the network, broken down by income or consumption decile.

Monthly utility bill for a subsistence consumption level, divided by typical monthly income of the poor. Actual monthly expenditure on utility services by connected households as a share of household budget, broken down by income or consumption decile. Actual monthly expenditure on substitutes for utility services by unconnected households as a share of household budget, broken down by income or consumption decile. Declared willingness to pay for utility service, broken down by income or consumption decile.

Estimated total resource cost of implementing the instrument. Estimated administrative cost of using the instrument.

Estimated percentage of beneficiaries that are poor. Estimated percentage of resources that leak away to unintended beneficiaries.

Anticipated behavioral impact on the utility. Anticipated behavioral impact on intended beneficiaries and the rest of the population.

Consumption Dominance Curves. Gini Index Decomposition.

Source: Prepared by the authors.

\section{VI}

\section{Final comments}

One of the difficulties of implementing pro-poor reforms is the need to take a coordinated approach across three different areas of public policy: privatization policy, social policy and regulatory policy. These three areas should be viewed as complementary, although the timing and institutional responsibility may differ in each case (Estache, Gómez-Lobo and Leipziger, 2000). Privatization policy and social policy actions have to be considered early on in the reform process. The regulatory framework should help to ensure that the original strategic priorities are followed through in implementation, and should incorporate the flexibility needed to adjust over time.
Privatization transactions are often spearheaded by the Ministry of Finance, which tends to view the process in narrow transactional terms, with the focus on maximizing the fiscal revenues from the asset sale. This is unfortunate because there are trade-offs between the sale value of assets and the economic and social impacts of the reform. For example, revenue considerations point towards keeping service tariffs high, minimizing rollout obligations, postponing the introduction of competition, and overlooking many of the details of regulation. But experience shows that this type of strategy is precisely that which is likely to be most damaging to the poor, and to the infrastructure sector 


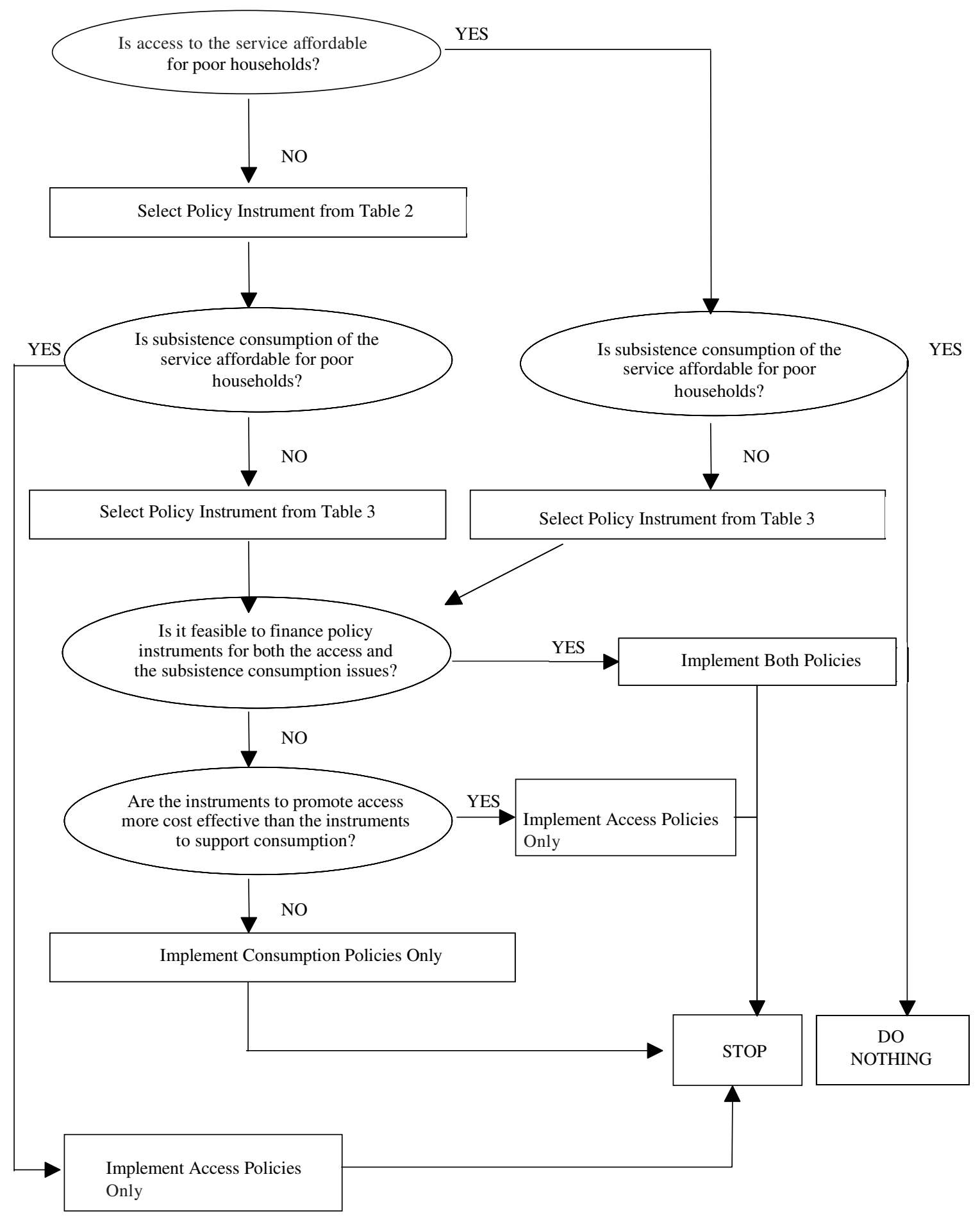


more generally. It is critical that at the outset of any privatization process there should be an attempt to form a balanced view between the macroeconomic and microeconomic impacts of the privatization. This points towards having a broader representation of interests on the transaction team, including the ministries responsible for infrastructure and social policy, and not only the Ministry of Finance. It also suggests that there is potentially a need to realign the incentives of those acting as advisers in the transactions, since they are often paid success-based fees that reflect the sale value of the infrastructure assets.

There are also linkages between social policy with regard to utilities and a country's wider strategy for poverty reduction and social protection that need to be understood. According to economic principles, social policy concerns are most efficiently addressed by channeling income transfers through the welfare system, rather than by subsidizing tariffs for particular goods and services (such as utilities). However, in many developing countries the welfare system is not well developed. Moreover, the administrative complexity and governance issues surrounding welfare payments may make utility services look like a practical secondbest approach to the achievement of social policy objectives. Nevertheless, while it is politically attractive to use utility pricing as a means of income redistribution, the evidence suggests that such redistribution can be regressive. If utility policy must form part of a country's social protection system, it is essential that the corresponding measures be much better designed than they have been in the past, and that they be coherent with the wider welfare framework.

The function of the regulator is to act as an arbiter between the competing interests of the operator, the State and civil society. After the initial privatization transaction is over, the decisions of the regulator have the greatest impact on the tariffs faced by low-income customers, the flexibility of service standards, the degree of competition in the market, and the speed with which networks are expanded into under-served areas. Since conflicts arise between social and financial concerns, governments must provide statutory clarification of the extent to which the regulator is responsible for meeting social objectives, and must specify which policy instruments are at his disposal. Recent evidence shows that effective regulation is important for ensuring that poor consumers get their fair share of the gains generated by the privatization process (Chisari and Estache, 1999). In Argentina, the gains from privatization increased when effective regulation was taken into account, and the benefits of effective regulation were found to be highest for the lowest income quintiles, simply because regulation acts as a mechanism for transferring rents from owners of capital to consumers of services produced with that capital.

This paper has discussed many ways in which infrastructure reform may impinge on the welfare of poor households, and it has suggested instruments for improving the impact of reform on the poor. While status quo arrangements in utility industries (e.g., public provision and poorly targeted subsidies) are not beneficial to poor households, many among the poor would benefit from the service expansion which may be made possible through privatization and which would allow them to avoid the high costs of alternative services. Moreover, there is evidence that poor households are willing or able to pay for reliable service. The way markets are restructured, the way competition is introduced and maintained, and the way regulatory commitments are implemented will determine whether reform is beneficial to the poor. Generally, the weaker the regulatory structure, the less likely it is that the concerns of the poor will be taken into account in public policy decisions.

At a broader level, what is really needed is political commitment. Infrastructure reform and privatization are not substitutes for responsible, redistributive welfare policies. But welfare reforms are complex and tend to be implemented only very slowly. Policies that lead to real welfare gains are needed in order to establish the credibility of reforms that are in the interest of all in the long run, and thus promote support for them. This is why, in the short run, policymakers will have to address many of the issues discussed in this paper. Whether infrastructure reformers can hope to succeed depends on the design of the reforms and the strategy for implementing them, but they also depend on the political will to put the poor at the centre of infrastructure reform and to counter the interest groups that may have a particularly strong incentive to maintain the status quo.

(Original: English) 


\section{Bibliography}

Ajwad, M. I. and Q. Wodon (2002a): Who benefits from an increase in access to public services at the local level? A marginal benefit incidence analysis for education and basic infrastructure, in S. Devaradjan, F. H. Rogers and L. Squire (eds.), Proceedings of the World Bank Economists' Forum, vol. 2, Washington, D.C., World Bank.

(2002b): Do local governments maximize access rates to public services across areas? A test based on marginal benefit incidence analysis, Washington, D.C., World Bank, unpublished.

Ajwad, I., C. Anguizola and Q. Wodon (2000): Estimating the welfare impact of privatization: Electricity in Bolivia, Washington, D.C., World Bank, unpublished.

Alcázar, L., M. Abdala and M. Shirley (1999): The case of the Aguas Argentinas concession, Washington, D.C., World Bank, unpublished.

Alexander, M. (2000): Privatizaciones en Argentina, in M. Baima and A. B. Rofman (comps.), Privatizaciones e impacto en los sectores populares, Buenos Aires, World Bank/Grupo de Trabajo de ongs sobre el Banco Mundial/Instituto de Investigaciones del Nuevo Estado.

Baffes, J. and A. Shah (1998): Productivity of public spending, sectoral allocation choices and economic growth, Economic Development and Cultural Change, vol. 46, No. 2, Chicago, Illinois, The University of Chicago.

Baker, B. and S. Tremolet (2000): Regulation of quality of infrastructure services in developing countries, paper presented at the International Conference on Infrastructure for Development: Private Solutions and the Poor, London, Public-Private Infrastructure Advisory Facility/World Bank.

Benítez, D., O. Chisari and A. Estache (2000): Measuring the fiscalefficiency-distribution trade-offs in Argentina's utilities privatization, Washington, D.C., World Bank, unpublished.

Brook, P. and N. Tynan (1999): Reaching the urban poor with private infrastructure. The Private Sector, Washington, D.C., World Bank.

Canning, D. (1998): A Database of World Infrastructure Stocks, 1950-1995, Policy research working paper, No. 1929, Washington, D.C., World Bank.

Canning, D., M. Fay and R. Perotti (1992): Infrastructure and growth, Revista di politica economica, vol. 82.

Carbonel, A. (2000): Water and sanitation in La Paz and El Alto in Bolivia: Aguas del Illimani, paper presented at the International Conference on Infrastructure for Development: Private Solutions and the Poor, London, Public-Private Infrastructure Advisory Facility/World Bank.

Chisari, O. and A. Estache (1999): The Needs of the Poor in Infrastructure Privatization: The Role of Universal Service Obligations. The Case of Argentina, Texto de discusión, No. 3, Buenos Aires, Universidad Argentina de La Empresa, Instituto de Economía, Centro de Estudios Económicos de la Regulación.

Chisari, O., A. Estache and C. Romero (1999): Winners and losers from the privatization and regulation of utilities: Lessons from a general equilibrium model of Argentina, The World Bank Economic Review, vol. 13, No. 2, Washington, D.C., World Bank.

Clert, C. and Q. Wodon (2001): The targeting of government programs in Chile, in E. Gacitúa-Mario and Q. Wodon (eds.),
Measurement and Meaning: Combining Quantitative and Qualitative Methods for the Analysis of Poverty and Social Exclusion in Latin America, World Bank technical paper, No. 518, Washington, D.C., World Bank.

Contreras, D. and A. Gómez-Lobo (2000): Subsidy Policies for the Utility Industries: A Comparison of the Chilean and Colombian Water Schemes, Santiago, Chile, University of Chile, Department of Economics.

De la Fuente, A. (2000): Growth and Infrastructure: A Survey, Washington, D.C., World Bank.

Eberts, R. W. (1990): Cross-Sectional Analysis of Public Infrastructure and Regional Productivity Growth, Working paper, No. 9004, Cleveland, Federal Reserve Bank of Cleveland.

Ehrhardt, D. (2000): Impact of market structure on service options for the poor, paper presented at the International Conference on Infrastructure for Development: Private Solutions and the Poor, London, Public-Private Infrastructure Advisory Facility/ World Bank.

Estache, A. and M. Fay (1995): Regional growth in Argentina and Brazil: Determinants and policy options, Washington, D.C., World Bank, unpublished.

Estache, A., V. Foster and Q. Wodon (2002): Accounting for the Poor in Infrastructure Reform: Learning from Latin America's Experience, Washington, D.C., World Bank.

Estache, A., A. Gómez-Lobo and D. Leipziger (2000): Utilities privatization and the poor's needs in Latin America: Have we learned enough to get it right?, paper presented at the International Conference on Infrastructure for Development: Private Solutions and the Poor, London, Public-Private Infrastructure Advisory Facility/World Bank.

Ferreira, P. C. and T. G. Malliagros (1998): Impactos produtivos da infra-estrutura no Brasil: 1950/95; Pesquisa e planejamento economico, vol. 28, No. 2, Rio de Janeiro, Institute of Applied Economic Research (IPEA).

Ferreira, P. C. (1996): Investimento em infra-estrutura no Brasil: fatos estilizados e relações de longo prazo, Pesquisa e planejamento economico, vol. 26, No. 2, Rio de Janeiro, IPEA, August.

Ferro, G. (1999): Evolución del cuadro tarifario de aguas argentinas: financiamiento de las expansiones en Buenos Aires, Texto de discusión, No. 11, Buenos Aires, Universidad Argentina de La Empresa, Instituto de Economía, Centro de Estudios Económicos de la Regulación.

Foster, V. (2001): Economic and financial evaluation of El Alto Pilot Project: Condominial water and sewerage systems and related innovations, Washington, D.C., World Bank, unpublished.

Foster, V. and C. Araujo (2002): Does infrastructure reform work for the poor? A case study from Guatemala, Washington, D.C., World Bank, unpublished.

Foster, V., A. Gómez-Lobo and J. Halpern (2000): Designing Direct Subsidies for Water and Sanitation Services. Panama: A Case Study, Policy research working paper, No. 2344, Washington, D.C., World Bank.

Foster, V. and O. Irusta (2001): A tale of two cities: Evaluating the impact of capitalization reforms on poor households in La Paz and El Alto, Washington, D.C., World Bank, unpublished.

Foster, V. and J. P. Tre (2000): Measuring the impact of energy interventions on the poor: An illustration from Guatemala, 
paper presented at the International Conference on Infrastructure for Development: Private Solutions and the Poor, London, Public-Private Infrastructure Advisory Facility/ World Bank.

Foster, V., J. P. Tre and Q. Wodon (2000): Energy Prices, Energy Efficiency, and Fuel Poverty, Washington, D.C., World Bank.

Galal, A. and others (1994): Welfare Consequences of Selling Public Enterprises: An Empirical Analysis, New York, Oxford University Press.

Garbacz, C. and H. G. Thompson (1997): Do lifeline programs promote universal telephone service for the poor, Public Utilities Fortnightly, vol. 135, No. 6, Vienna, Virginia, Public Utilities Reports, March.

Gómez-Lobo, A. (1996): The welfare consequences of tariff rebalancing in the domestic gas market, Fiscal Studies, vol. 17 , No. 4.

Jadresic, A. (2000): A case study on subsidizing rural electrification in Chile, in P. Brooks and S. Smith, Energy Services for the World's Poor. Energy and Development Report, Washington, D.C., World Bank.

Kariuki, M. and G. Acolor (2000): Delivery of water supply to lowincome urban communities through the Teshie Tanker Owners Association: A case study of public-private initiatives in Ghana, paper presented at the International Conference on Infrastructure for Development: Private Solutions and the Poor, London, Public-Private Infrastructure Advisory Facility/ World Bank.

Komives, K. and P. Brook (1999): Expanding Water and Sanitation Services to Low-Income Households: The Case of the La PazEl Alto Concession, Viewpoint note, No. 178, Washington, D.C., World Bank.

Komives, K., D. Whittington and X. Wu (2000): Infrastructure coverage and the poor: A global perspective, paper presented at the International Conference on Infrastructure for Development: Private Solutions and the Poor, London, PublicPrivate Infrastructure Advisory Facility/World Bank.

Maddock, R. and E. Castaño (1991): Welfare impact of rising block pricing: Electricity in Colombia, The Energy Journal, vol. 12, No. 4, Canada, International Association for Energy Economics (IAEE).

Makdissi, P. and Q. Wodon (2002): Consumption dominance curves: Testing for the impact of indirect tax reforms on poverty, Economics letters, No. 75, Amsterdam, The Netherlands, North-Holland..

Nadiri, M. I. and T. P. Mamuneas (1994): The effects of public infrastructure and R\&D capital on the cost structure and performance of U.S. manufacturing industries, Review of Economics and Statistics, vol. 76, No. 1, Cambridge, Massachusetts, Harvard University.
Siaens, C. and Q. Wodon (2002): Impact of access to basic infrastructure services on poverty and inequality, Washington, D.C., World Bank, unpublished.

Solo, T. M. (1999a): Small-scale entrepreneurs in the urban water and sanitation market, Environment and Urbanization, vol. 11, No. 1, London, International Institute for Environment and Development (IIED).

(1999b): Aguas que yo vendo bien, aguas que yo vendo mal, Independent Water Entrepreneurs in Latin America: Findings in Six Cities, Washington, D.C., World Bank.

Solo, T. M. and M. Paniagua (1999): The other private participation in water and sanitation: Tales of small independent providers in Latin American cities, Washington, D.C., World Bank, unpublished.

Ugaz, C. and C. Waddams Price (2002): A Fair Deal for Customers? The Impact of Infrastructure Reform in Latin America, Japan, United Nations University (UNU), World Institute for Development Economics Research (WIDER)

Vélez, C. E (1995): Gasto social y desigualdad: logros y extravíos, Santafé de Bogotá, Misión Social/Departamento Nacional de Planeación (DNP).

Wodon, Q. (1999): Service universel et pauvreté: les aides à l'énergie, in M. Chefferet and others (coords.), Service universel, compétition, et télécommunications, Cahiers du Centre de Recherche Informatique et Droit, No. 15, Namur, Belgium, Facultés Universitaires Notre-Dame de la Paix.

(2000a): An assessment of EDF's low income energy assistance programs, Washington, D.C., World Bank, unpublished.

(2000b): Public utilities and low income customers: A marketing approach, International Journal of Public Sector Management, No. 13.

(2000c): Low income energy assistance and disconnection in France, Applied Economics Letters, vol. 7, No. 12, London, Taylor \& Francis Group.

(2000d): Poverty and Policy in Latin America and the Caribbean, World Bank technical paper, No. 467, Washington, D.C., World Bank.

Wodon, Q. and I. Ajwad (2002): Infrastructure services and the poor: Providing connection or consumption subsidies?, Washington, D.C., World Bank, unpublished.

Wodon, Q., I. Ajwad and C. Siaens (2002): Targeting electricity subsidies: Lifeline or means-testing?, Washington, D.C., World Bank, unpublished.

Wodon, Q. and S. Yitzhaki (2002): Inequality and social welfare, in J. Klugman (ed.), Poverty Reduction Strategies Source Book, Washington, D.C., World Bank. 